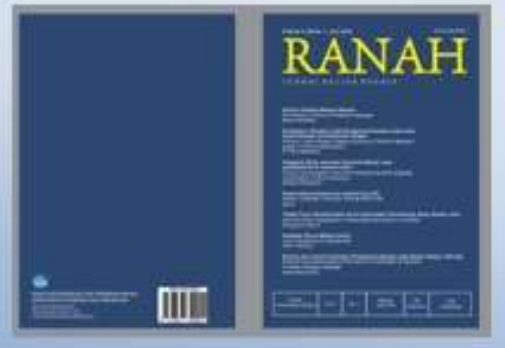

Ranah: Jurnal Kajian Bahasa

http://ojs.badanbahasa.kemdikbud.go.id/jurnal/index.php/jurnal_ranah

p-ISSN: $2338-8528$

e-ISSN: $2578-8111$

\title{
ANALISIS HUBUNGAN PENGUASAAN KOSAKATA DAN KEMAMPUAN MEMAHAMI UNSUR INTRINSIK CERPEN SISWA SMP DI KOTA KENDARI
}

\author{
The Correlation Analysis Between Vocabulary Mastery and Comprehending Short Story \\ Instrinsical Components Ability of SMP Students in Kendari
}

\author{
Firman A.D., Heksa Biopsi Puji Hastuti, Sukmawati, Rahmawati \\ Kantor Bahasa Sulawesi Tenggara \\ firmanad041@gmail.com
}

Naskah Diterima Tanggal 26 Februari 2018_-Direvisi Akhir Tanggal 22 Mei 2019_Disetujui Tanggal 10 juni 2019

Doi: $10.26499 /$ rnh.v8i1.636

\begin{abstract}
Abstrak
Permasalahan dalam penelitian ini adalah bagaimana hubungan penguasaan kosakata dengan kemampuan memahami unsur intrinsik VIII SM di Kota Kendari. Dengan demikian, tujuannya adalah mendeskripsikan penguasaan kosakata dan kemampuan memahami unsur intrinsik cerpen dan memperlihatkan ada atau tidak adanya hubungan antara penguasaan kosakata dengan kemampuan memahami unsur intrinsik cerpen siswa. Penelitian menggunakan metode statistik. Data dianalisis secara kuantitatif deskriptif dan kuantitatif parametris dengan menggunakan uji Korelasi Product Moment dan Regresi Linear. Setelah analisis deskriptif kuantitatif, dilakukan tahap uji korelasi untuk mengetahui hubungan antarvariabel. Hasil penelitian ini menunjukkan bahwa penguasaan kosakata siswa SMP memiliki nilai rata-rata 8,84 (48\%) yang masuk dalam kategori sedang. Indikator penguasaan kosakata yang paling menonjol memberikan kontribusi ialah memahami kata yang mengalami ameliorasi-peyorasi, perluasanpenyempitan dengan nilai rata-rata $2,75(32,7 \%)$. Sementara, kemampuan memahami unsur intrinsik cerpen siswa SMP memiliki nilai rata-rata 10,42 $(45,25)$, pada umumnya termasuk kategori sedang. Indikator kemampuan memahami unsur intrinsik cerpen yang paling menonjol memberikan kontribusi ialah indikator memahami tokoh dan penokohan dalam cerpen dengan nilai rata-rata 3,23 (44,25\%). Penguasaan kosakata memiliki hubungan yang positif dan signifikan dengan kemampuan memahami unsur intrinsik cerpen pada siswa SMP kelas VIII di Kota Kendari, dengan nilai $r_{\text {hitung }}=0,359$ $>\mathrm{r}_{\text {tabel }}=0,250$ dan nilai Sig $(\rho)<\alpha=0,05$, dan $\mathrm{t}_{\text {hitung }}=14,246>\mathrm{t}_{\text {tabel }}=1,645$ dan nilai Sig $(\rho)<\alpha=0,05$. Besarnya kontribusi penguasaan kosakata $(X)$ terhadap kemampuan memahami unsur intrinsik cerpen (Y) siswa SMP adalah 12,9\%, dan selebihnya dipengaruhi oleh faktor lain yang tidak terkait dengan penelitian ini.
\end{abstract}

Kata kunci: penguasaan kosakata, unsur intrinsik cerpen, siswa SMP, Kendari

\section{Abstract}

This research problem is how is the relation between vocabulary mastery and short story intrinsical components comprehension ability of VIII grade students in Kendari City. The research is aimed to describe how vocabulary mastery and comprehending short story 
intrinsical components ability and how the relationship between both of them by the students. This research used statistic method. Data was analyzed descriptivequantitatively and parametric-quantitatively by using Product Moment Correlation and Linear Regression. After doing descriptive-quantitative analysis, in order to understand the relationship intervariabel, then was conducted correlation test. Result of this research shows that vocabulary mastery have average values 8,84 (48\%) which included in medium category. Vocabulary mastery indicator which have most prominent contribution is words comprehending that has pejorative-amelirative meaning, extension-constriction meaning by average value 2,75 (32,7\%). Meanwhile, comprehending short story intrinsical components ability has average value 10,42 $(45,25)$, which included generally in medium category. Indicator of comprehending short story intrinsical components ability which have most prominent contribution is figure and characterization by average value 3,23 (44,25\%). Vocabulary mastery has positive and significant correlation with comprehending short story intrinsical components ability of SMP students at value $\mathrm{r}_{\mathrm{xy}}=0,359>r_{\text {table }}=0,250$ and value of Sig $(\rho)<\alpha=$ 0,05 , and $t_{x y}=14,246>t_{\text {table }}=1,645$ dan value of Sig $(\rho)<\alpha=0,05$. Contribution value vocabulary mastery $(X)$ toward comprehending short story intrinsical components ability $(Y)$ is $12,9 \%$, and the rest, is influenced by other factors that are not related with this research.

Keywords: vocabulary mastery, short story intrinsical component, SMP student, Kendari

How to Cite: D, Firman. A, dkk. (2018). Analisis Hubungan Penguasaan Kosakata dan Kemampuan Memahami Unsur Intrinsik Cerpen Siswa Smp Di Kota Kendari. Ranah: Jurnal Kajian Bahasa, 8 (1), 123-142. doi: https://doi.org/10.26499/rnh.v8i1.636

\section{PENDAHULUAN}

Pengajaran bahasa dan sastra Indonesia di berbagai jenjang pendidikan mencakup kegiatan apresiatif sekaligus kegiatan kreatif. Selama ini, pelajaran bahasa dan sastra Indonesia masih sering diaggap kurang penting, baik oleh siswa, orang tua siswa sebagai mitra guru, maupun oleh guru. Terlebih jika guru memiliki pengetahuan, kemampuan, dan minat apresiasi sastra yang rendah. Hal tersebut menyebabkan pengajaran bahasa dan sastra Indonesia sebagai mata pelajaran yang sejatinya penting dan sangat bermanfaat bagi peserta didik disampaikan hanya sekadar memenuhi tuntutan kurikulum. Guru tidak berusaha membuat penyajian pelajaran menjadi lebih hidup dan bergairah.

Model penyampaian seperti itu membuat pelajaran bahasa dan sastra Indonesia cenderung tidak diminati dan kurang mendapat tempat di hati siswa. Padahal, bila kita kaji secara mendalam, tujuan pengajaran bahasa dan sastra Indonesia di sekolah adalah untuk menumbuhkan keterampilan, rasa cinta, dan penghargaan siswa terhadap bahasa dan sastra Indonesia. Dengan demikian, tugas guru bahasa dan sastra Indonesia tidak 
hanya memberi pengetahuan (aspek kognitif), tetapi juga keterampilan (aspek psikomotorik) dan menanamkan rasa cinta (aspek afektif), baik melalui kegiatan di dalam kelas maupun di luar kelas (Hamid, 2007).

Pengajaran sastra di sekolah tidak untuk membuat siswa menjadi seorang sastrawan atau seorang ahli sastra, melainkan untuk menanamkan apresiasi sastra. Dalam ranah pragmatik, makna sebuah karya sastra ditentukan oleh publik pembacanya selaku penyambut karya tersebut (Noor, 2005). Karya sastra dipandang sebagai karya seni yang berhasil jika dapat berguna bagi publiknya, seperti menyenangkan, memberi kenikmatan, dan mendidik. Pandangan ini dikembangkan dari pendapat Horatius, fungsi sastra harus menyenangkan dan berguna atau 'dulce et utile'.

Berhasil dan tidaknya pembelajaran sastra dipengaruhi oleh beberapa faktor yang secara umum mencakup tiga elemen utama, yaitu siswa, guru, dan lingkungan. Sebagai subjek pembelajaran, faktor siswa menjadi faktor utama yang menentukan keberhasilan tercapainya tujuan pembelajaran. Kemampuan apresiasi sastra siswa di antaranya ditentukan oleh minat dan kemampuan membaca teks sastra. Kemampuan membaca dan memahami bacaan (termasuk teks sastra) salah satunya dipengaruhi oleh penguasaan kosakata siswa. Dengan demikian, penguasaan kosakata siswa diasumsikan mempunyai peranan yang sangat penting dalam kemampuan memahami teks sastra yang pada gilirannya berpengaruh pula pada kemampuan apresiasi sastra siswa.

Elemen kedua adalah guru. Guru yang kurang memahami sastra, kurang mengoptimalkan proses pembelajaran sastra, dan kurang memberikan penugasan untuk membaca karya sastra dapat menyebabkan tidak tercapainya tujuan pembelajaran sastra di sekolah. Elemen ketiga adalah lingkungan, meliputi ketersediaan bacaan dan atmosfer saat proses pembelajaran atau saat membaca karya sastra.

Kemampuan apresiasi sastra siswajuga dipengaruhi oleh sikap bahasa. Hasil penelitian sikap bahasa siswa SMP se-Kota Kendari olehKantor Bahasa Provinsi Sulawesi Tenggara menunjukkan bahwa sikap bahasa siswa SMP di Kota Kendari baik (Uniawati, Zakiyah M. Husba, 2014). Artinya, yang perlu dikaji kali ini adalah faktor kemampuan siswa memahami teks sastra, terutama teks sastra yang terdapat dalam bahan ajar Bahasa Indonesia.

Apresiasi sastra yang menjadi salah satu standar kompetensi siswa SMP kelas VII adalah memahami unsur intrinsik yang membangun sebuah prosa (cerita pendek). 
Memahami unsur intrinsik sebuah karya sastra, yang dalam penelitian ini dipersempit dalam lingkup cerita pendek, merupakan pintu pertama yang harus dilakukan untuk dapat memaknai karya. Kemampuan itulah yang akan menjadi fokus kajian. Diperkirakan ada keterkaitan yang erat antara memahami cerita pendek sebagai teks sastra dan penguasaan kosakata yang terdapat di dalam teks tersebut. Oleh karena itu, tulisan inimengangkat sebuah penelitian yang berfokus pada permasalahan tersebut.

Permasalahan yang relevan dengan penelitian ini adalah yang dilakukan oleh Wicaksono (Wicaksono, 2011) yang mengangkat permasalahan hubungan antara minat terhadap karya sastra dan kemampuan membaca pemahaman dengan kemampuan apresiasi sastra pada siswa kelas 2 SMU 1 Sleman. Dengan berlandaskan asumsi bahwa seorang pembaca karya sastra dapat menikmati isi bacaannya apabila dia mampu memahami isi yang terkandung di dalamnya.Wicaksono memunculkan masalah adanya hubungan antara kemampuan membaca pemahaman dengan kemampuan apresiasi sastra. Berbeda dengan permasalahan yang diajukan oleh Wicaksono, penelitian ini memfokuskan permasalahan pada hubungan antara penguasaan bahasa dengan tingkat apresiasi sastra siswa kelas VIII SMP di Kota Kendari.

Berangkat dari asumsi awal bahwa kemampuan mengapresiasi karya sastradapat dipengaruhi oleh penguasaan bahasa dan dengan mengacu pada uraian latar belakang, rumusan masalah penelitian iniadalah "bagaimana penguasaan kosakata dan kemampuan memahami unsur intrinsik cerpen oleh siswa kelas VIII SMP se-Kota Kendari dan bagaimana hubungan antara penguasaan kosakata dengan kemampuan memahami unsur intrinsik cerpen siswa SMP kelas VIIIdi Kota Kendari?”

Sejalan dengan itu, penelitian ini bertujuan mendeskripsikan penguasaan kosakata dan kemampuan memahami unsur intrinsik cerpen siswa kelas VIII SMP di Kota Kendari dan memperlihatkan ada atau tidak adanya hubungan antara penguasaan kosakata dengan kemampuan memahami unsur intrinsik cerpen.Hasil penelitian ini dapat dijadikan acuan untuk menentukan regulasi dan kebijakan, khususnya mengenai pengajaran bahasa dan sastra Indonesia tingkat SMP.

\section{LANDASAN TEORI}

\section{Penguasaan Kosakata}

Suatu keterampilan bahasa tidak dapat terlepas dari penguasaan kosakata sebab inti dari suatu bahasa adalah kata. Kosakata merujuk pada kekayaan kata suatu bahasa 
tertentu. Berdasarkan hal tersebut, terdapat banyak definisi kosakata yang dikemukakan oleh para ahli bahasa. Soedjito (dalam Tarigan, 1991: 441) mengemukakan kosakata dapat diartikan sebagai berikut. (1) semua kata yang terdapat dalam satu bahasa; (2) kekayaan kata yang dimiliki oleh seorang pembicara atau penulis; (3) kata yang dipakai dalam suatu bidang ilmu pengetahuan; dan (4) daftar kata yang disusun seperti kamus disertai penjelasan secara singkat dan praktis.

Djiwandono (2011: 126) mengemukakan bahwa kosakata adalah perbendaharaan kata dalam berbagai bentuknya yang meliputi: kata-kata lepas dengan atau tanpa imbuhan dan katakata yang merupakan gabungan dari kata-kata yang sama atau berbeda, masing-masing dengan artinya sendiri. Kosakata adalah kekayaan kata yang dimiliki seorang pembicara, penulis, atau suatu bahasa. Kosakata juga merupakan komponen bahasa yang memuat semua informasi tentang makna dan pemakaian kata dalam bahasa.

Berdasarkan pendapat tersebut dapat disimpulkan bahwa kosakata adalah kumpulan kata yang digunakan seseorang dalam kegiatan berbahasa. Penguasaan kosakata sangat diperlukan oleh seseorang untuk memahami dan menggunakan kumpulan kata yang dimilikinya untuk mengekspresikan pikiran dan rasa dalam berbagai ruang lingkup kehidupan seperti dalam kegiatan berbahasa.

Tarigan (2015: 2) mengemukakan bahwa kualitas keterampilan berbahasa seseorang bergantung pada kuantitas dan kualitas kosakata yang dimilikinya. Semakin kaya kosakata yang kita miliki, semakin besar pula kemungkinan kita terampil berbahasa. Oleh karena itu, pengajaran kosakata di sekolah harus menjadi dasar bagi pengembangan keterampilan berbahasa siswa.

Kosakata sebagai salah satu unsur pembelajaran bahasa Indonesia di sekolah menjadi dasar penguasaan siswa terhadap materi pelajaran bahasa Indonesia dan penguasaan mata pelajaran lain. Penguasaan kosakata akan memengaruhi cara berpikir dan kreativitas siswa dalam proses pembelajaran bahasa sehingga penguasaan kosakata dapat menentukan kualitas seorang siswa dalam berbahasa (Kasno, 2014). Kualitas keterampilan berbahasa seseorang bergantung pada kuantitas kosakata yang dimilikinya. Makin banyak kosakata yang dimiliki seseorang, makin besar pula keterampilan berbahasanya. 
Pendapat tersebutdapat dipahami bahwa kualitas dan kuantitas perbendaharaan kata yang dimiliki oleh siswa akan membantu siswa dalam menyerap berbagai informasi yang disampaikan para pengajar atau informasi dari berbagai sumber belajar lainnya. Penguasaan kosakata yang baik sangat memengaruhi kemampuan siswa dalam berkomunikasi, baik lisan maupun tulisan.

Menurut Djiwandono (2008) penguasaan kosakata dapat dibedakan dalam penguasaan aktif-produktif dan pasif-reseptif. Pengertian penguasaan kosakata aktifproduktif, yaitu kosakata yang telah dikuasai dan dipahami dapat digunakan oleh pemelajar bahasa secara wajar tanpa ada kesulitan dalam berkomunikasi atau berbahasa. Penguasaan kosakata pasif-reseptif merupakan kosakata yang telah dikuasai hanya dapat dipahami oleh pemelajar bahasa dari ungkapan bahasa orang lain, tetapi ia tidak mampu menggunakan kosakata secara wajar dalam berkomunikasi atau berbahasa.

Kosakata merupakan komponen inti dari kemampuan berbahasa dan merupakan dasar bagaimana siswa mampu berbicara baik, mendengarkan, membaca, dan menulis. Tanpa kosakata yang luas dan strategi yang tepat untuk memperoleh kosakata baru, siswatidakdapat mengoptimalkan potensi yang mereka miliki serta menjadi enggan untuk memanfaatkan peluang di sekitar. Oleh karena itu, guru dituntut untuk melakukan pembelajaran dan pengajaran kosakata dengan kreatif sehingga menjadi lebih bermakna untuk menarik siswa dalam mempelajarinya. Selain itu, menurut Widaningsih (2014: 46) bahwa ketiadaan ide, gagasan yang akan ditulis menjadi alasan utama peserta didik atau siapa pun berhenti atau enggan menulis. Oleh karena itu, menjadi penting bagi para pendidik untuk mempelajari teknik membangun konteks agar pada tahap ini kuriositas peserta didik terlecutkan.

Berdasarkan pengamatan Zalmansyah (2018: 230), dalam pembelajaran guru menggunakan pendekatan konvensional sehingga dariwaktu ke waktu pembelajaran terasa membosankan. Siswa tidak tertarik untuk belajar,tidak termotivasi, dan merasa tidak semangat untuk belajar bahasa Indonesia. Situasiseperti ini terjadi di sekolah, tempat penelitian ini dilakukan.Dari satu kelas yang diamati, dengan jumlah siswa 38 anak, diketahui bahwa pada aspek menulisnya, siswa yang tidak tuntas berjumlah 26 anak, sedangkan siswa yang mencapai ketuntasanbelajar 12 anak dari Kemampuan Ketuntasan Minimal (KKM) yang telah ditentukan, yaitu 67. 
Tarigan (2015) menjelaskan bahwa kualitas keterampilan berbahasa seseorang bergantung pada kuantitas dan kualitas kosakata yang dimiliki. Semakin kaya kosakata yang dimiliki, semakin besar pula kemungkinan kita terampil berbahasa. Tanpa penguasaan kosakata yang memadai, sangat sulit bagi orang tersebut untuk mengadakan interaksi secara baik. Pada saat kegiatan membaca dan menyimak diperlukan kemampuan pemahaman.Sementara, pada kegiatan menulis dan berbicara diperlukan kemampuan penggunaan kosakata.

Tarigan (2015: 68) menyebutkan pengembangan kosakata terdiri atas sinonim, antonim, dan homonim. Sinonim merupakan kata-kata yang bentuknya berbeda tetapi artinya sama. Pengertian 'sama' di sini tidak berlaku mutlak, sebab dalam pemakaian sehari-hari tidak ada dua kata yang sama betul artinya. Sinonim dapat berarti memiliki makna yang sama atau hampir sama, tetapi tidak selalu dapat saling menggantikan dalam kalimat. Lebih lanjut, ia mengemukakan bahwa sinonim merupakan kata-kata yang mengandung arti pusat yang sama, tetapi berbeda dalam nilai kata. Menelaah sinonim merupakan suatu pendekatan yang sangat baik dan menghemat waktu bagi telaah kosakata. Jadi,dapat disimpulkan bahwa sinonim merupakan persamaan arti atau makna suatu kata.

Verhaar (dalam Rosdiana, 2008 4) mendefinisikan antonim sebagai ungkapan yang dianggap bermakna kebalikan dari ungkapan lain. Selanjutnya, Chaer (2011) mengemukakan bahwa antonim adalah dua buah kata yang maknanya "dianggap" berlawanan. Dikatakan "dianggap" berlawanan dari dua kata yang berantonim sangat relatif, ada yang mutlak berlawanan dan ada yang tidak mutlak berlawanan.

Lain halnya dengan homonim. Secara harfiah, homonim berarti kata yang sama lafal dan ejaanya, tetapi berbeda maknanya. Tarigan (2015) menjelaskan bahwa homonim merupakan kata-kata yang bunyinya sama, tetapi maknanya berlainan.Berdasarkan pendapat tersebut dapat disimpulkan bahwa homonim merupakan kata yang mempunyai bunyi dan bentuk yang sama tetapi artinya berbeda.

\section{Apresiasi Sastra}

Pembelajaran sastra di sekolah merupakan bagian dari mata pelajaran Bahasa Indonesia yang harus saling melengkapi. Menurut Dirgantara (2012) bahwa sastra merupakan sistem tanda yang mempunyai makna dengan bahasa sebagai mediumnya. 
Konvensi-konvensi sastra memberikan sokongan yang besar bagi perembangan bahasa. Dalam pembelajaran sastra, siswa tidak hanya dituntut untuk memahami teori sastra,tetapi jugadituntut untuk memiliki kemampuan dalam mengapresiasi karya sastra.

Yang dimaksud dengan apresiasi sastra adalah penghargaan, penilaian, dan pengertian terhadap karya sastra, baik yang berbentuk puisi, prosa, maupundrama, atau suatu kegiatan menggauli sastra dengan sungguh-sungguh hingga tumbuh pengertian, penghargaan, kepekaan pikiran kritis, dan kepekaan perasaan yang baik terhadap cipta sastra. Untuk dapat mengapresiasi karya sastra dengan baik, anak didik harus diarahkan atau dibimbing dalam membaca, menulis, dan mengkritisi karya sastra. Hal itu sejalan dengan pendapat Aminuddin (dalam Dirgantara, 2012) bahwa untuk mampu mengapresiasi karya sastra harus dilakukan dengan cara terus-menerus menggauli karya sastra. Membaca karya sastra secara langsung akan membawa anak didik pada pemahaman nilai-nilai yang terkandung dalam karya sastra dan mengajak anak didik untuk ikut menghayati pengalaman-pengalaman yang disajikan. Pembelajaran apresiasi sastra bertujuan mengembangkan kepekaan siswa terhadap nilai-nilai indrawi, afektif, keagamaan, dan nilai sosial secara sendiri-sendiri atau gabungan keseluruhan, seperti yang tercermin di dalam karya sastra. Pada hakikatnya, pengajaran sastra adalah menciptakan situasi siswa membaca dan merespons karya sastra serta membicarakan secara bersama dalam kelas. Menurut Andayani (2009), pembelajaran apresiasi sastra berhubungan dengan kegiatan bersastra, yaitu mendengar atau membaca karya sastra dengan penghayatan dan menulis sastra. Pembelajaran apresiasi sastra memperkenalkan kepada peserta didik nilai-nilai yang dikandung karya sastra dan mengajak peserta didik ikut menghayati pengalaman-pengalaman yang disajikan.

Ada beberapa manfaat yang bisa diperoleh dalam mengapresiasi sastra anak,yaitu manfaat estetis adalah manfaat tentang keindahan yang melekat pada sastra anak; manfaat pendidikan adalah memberi berbagai informasi tentang proses pengubahan sikap dan tata laku seseorang atau kelompok orang dalam usaha mendewasakan manusia melalui pengajaran dan latihan; manfaat kepekaan batin atau sosial merupakan upaya untuk selalu mengasah batin agar mudah tersentuh oleh hal-hal yang bersifat batiniah ataupun sosial; manfaat menambah wawasan, artinya memberi tambahan informasi, pengetahuan, pengalaman hidup, dan pandangan-pandangan 
tentang kehidupan; manfaat pengembangan kejiwaan atau kepribadian adalah mampu menghaluskan budi pekerti seorang apresiator.

\section{Unsur Intrinsik dalam Karya Sastra}

Pemahaman nilai estetik dan nilai tematik yang terkandung dalam karya sastra dimungkinkan jika peserta didik dapat memahami unsur intrinsik dan unsur ekstrinsik karya sastra. Nilai estetik eratkaitannya dengan prinsip estetika yang membentuk keindahan karya sastra. Pada cerpen dan novel, nilai estetik dapat dicermati pada alur (plot), karakterisasi, latar, dan sudut pandang. Di dalam plot ada paparan, krisis/konflik, klimaks, dan penyelesaian, sedangkan nilai tematik meliputi tema yang terurai melalui keseluruhan isi dan pesan karya sastra. Pada aspek tematiklah karya sastra menempatkan pesan moral, budaya, agama, sosial, politik, kemanusiaan, keadilan, kesederajatan, cinta, kasih sayang, dan pesan-pesan mulia lain yang oleh pengarang dianggap penting untuk disampaikan kepada pembaca.

Unsur intrinsik sebagai unsur yang membangun sebuah karya sastra dari dalam karya sastra berperan penting dalam memberikan pemahaman nilai estetika dan nilai tematik. Pada karya cerpen dan novel, unsur-unsur tersebut meliputi penokohan, alur, tema, latar, dan sudut pandang.

Tokoh cerita menurut Abrams (dalam Nurgiyantoro, 2009) adalah orang-orang yang ditampilkan dalam suatu karya naratif atau drama yang oleh pembaca ditafsirkan memiliki kualitas moral dan kecenderungan tertentu seperti yang diekspresikan dalam ucapan dan yang dilakukan dalam tindakan. Selain istilah tokoh, istilah penokohan mempunyai cakupan yang lebih luas. Tokoh cerita menempati posisi strategis sebagai pembawa dan penyampai pesan, amanat, moral, atau sesuatu yang sengaja ingin disampaikan kepada pembaca. Dilihat dari segi peranan dan tingkat pentingnya tokoh dalam sebuah cerita terdiri atas tokoh utama (central character, main character) dan tokoh tambahan (peripheral character).

Latar dapat dibedakan ke dalam tiga unsur pokok, yaitu latar tempat, menyaran pada lokasi terjadinya peristiwa; latar waktu berkaitan dengan masalah "kapan" terjadinya peristiwa; latar sosial menyaran pada hal-hal yang berhubungan dengan perilaku kehidupan sosial masyarakat di suatu tempat; sudut pandang menyaran pada cara sebuah cerita dikisahkan sebagai sarana yang dipergunakan pengarang untuk 
menyajikan tokoh, tindakan, latar, dan berbagai peristiwa yang membentuk cerita; tema dan amanat berkaitan dengan makna yang dikandung dalam sebuah cerita atau gagasan dasar umum yang menopang sebuah karya sastra serta yang terkandung di dalam teks sebagai sebuah struktur semantis dan yang menyangkut persamaan-persamaan atau perbedaan-perbedaan (Nurgiyantoro, 2009).

\section{METODE PENELITIAN}

Penelitian ini bersifat statistik, yaitu menggunakan statistik deskriptif dan statistik parametris. Lokasi penelitian dilakukan di sekolah menengah pertama yang ada di Kota Kendari. Data yang digunakan terdiri atas data primer, yakni data kuantitatif yang berbentuk angka yang dijaring melalui pengumpulan data melalui tes (kuesioner) dan juga diperoleh melalui wawancara terbuka, dan data sekunder berupa referensi yang berhubungan dengan pertanyaan penelitian yang mendukung proses analisis data melalui penelusuran pustaka.

Populasi penelitian ini adalah semua siswa kelas VIII SMP di Kota Kendari. Penarikan sampel menggunakan teknik cluster random sampling dengan mempertimbangkan sifat dan penyebaran populasi. Menurut Zuriah (2005: 125) berdasarkan sifat dan penyebaran populasi, sampel yang diambil dari subpopulasi berdasarkan daerah penyebarannya yang telah ditetapkan. Tujuh sekolah menengah tingkat pertama di Kota Kendari dipilih dengan mempertimbangkan keterwakilan status sekolah dan lokasi sekolah. Ketujuh sekolah yang dipilih adalah sebagai berikut.

\section{Tabel 1}

Distribusi SampelPenelitian

\begin{tabular}{clc}
\hline No. & \multicolumn{1}{c}{ Nama Sekolah } & Jumlah Sampel \\
\hline 1. & SMPN 1 Kendari & 48 \\
\hline 2. & SMPN 4 Kendari & 67 \\
\hline 3. & SMPN 5 Kendari & 120 \\
\hline 4. & SMPN 12 Kendari & 45 \\
\hline 5. & SMPN 15 Kendari & 80 \\
\hline 6. & SMPS Frater Kendari & 20 \\
\hline 7. & MTsS Muadz bin Jabbal & 20 \\
\hline & Total JumlahSampel & 400 \\
\hline
\end{tabular}


Dari ketujuh sekolah tersebut diambil sebanyak empat ratus siswa kelas VIII. Jumlah sampel tiap sekolah bervariasi karena disesuaikan dengan komposisi jumlah murid tiap sekolah. Jumlah tersebut dianggap sudah dapat mewakili keseluruhan populasi yang tersebar di 38 sekolah menengah pertama yang ada di Kota Kendari.

Penelitian ini merupakan penelitian korelasional yang melibatkan dua variabel. Mengacu pada Zuriah (2005: 56), dalam penelitian ini penguasaan kosakata merupakan variabel prediktor atau variabel bebas dan kemampuan memahami unsur intrinsik cerita pendek sebagai variabel kriterium atau variabel terikat. Materi kuesioner terdiri atas pertanyaan mengenai pengetahuan dan penguasaan kosakata (denotatif-konotatif, ameliorasi-peyorasi, afiksasi, kelas kata, bentuk baku, dan bentuk tidak baku) serta pemahaman unsur intrinsik cerita pendek (meliputi elemen tokoh dan penokohan, latar waktu dan tempat, alur, tema, dan amanat cerita).

Datakemudian dianalisis dengan menggunakan uji Korelasi Product Moment danRegresi Linear. Setelah analisis deskriptif kuantitatif, dilakukan tahap uji korelasi untuk mengetahui hubungan antarvariabel. Untuk penghitungan statistik digunakan program komputer SPSS (Statistics Package for Social Scientist).

Indikator variabel bebas (penguasaan kosakata) ditetapkan ada lima: penguasaan makna terdiri atas duaunsur, yaknidenotatif-konotatif dan ameliorasi-peyorasi; afiksasi, kelas kata;dan bentuk baku dan bentuk tidak baku. Indikator pemahaman unsur intrinsik cerpen meliputi pemahaman atas elemen tokoh dan penokohan, latar cerita, alur cerita, tema cerita, dan amanat cerita. Hasil analisis data disajikan dalam bentuk tabel dengan pembahasan secara deskriptif kualitatif sebagai acuan dalam penarikan simpulan penelitian.

Hipotesis yang menjadi asumsi awal penelitian adalah bahwa ada hubungan antara penguasaan kosakata bahasa Indonesia dan kemampuan memahami unsur intrinsik cerita pendek siswa kelas VIII SMP di Kota Kendari. Semakin tinggi tingkat penguasaan bahasa Indonesia, akan semakin baik pula kemampuan mengapresiasi teks sastra, dalam hal ini memahami unsur intrinsik cerita pendek seperti tokoh dan penokohan, latar, alur, tema, serta amanat cerita.

Instrumen dalam penelitian ini berupa kuesioner yang memuat indikatorindikator untuk setiap variabel (lihat Tabel 2).

\section{Tabel 2}




\section{Variabel, Instrumen, danIndikatorPenelitian}

\begin{tabular}{lll}
\hline Variabel & $\begin{array}{l}\text { Instrumen } \\
\text { (nomor soal) }\end{array}$ & Indikator \\
\hline Penguasaan kosakata & $\begin{array}{l}2,4,28,30 \\
6,8,22,24\end{array}$ & $\begin{array}{l}\text { 1. Memahami afiksasi/kelas kata } \\
\text { bersinonim/berantonim }\end{array}$ \\
\cline { 2 - 3 } & $10,12,26,32$ & $\begin{array}{l}\text { 3. Memahami kata yang mengalami } \\
\text { ameliorasi-peyorasi, perluasan- } \\
\text { penyempitan }\end{array}$ \\
\cline { 2 - 3 } & $14,16,36,38$ & $\begin{array}{l}\text { 4. Memahami kata baku-tidak baku } \\
\text { Kemampuan memahami } \\
\text { unsur intrinsik cerpen }\end{array}$ \\
\cline { 2 - 3 } & $18,20,34,40$ & $\begin{array}{l}\text { 5.Memahami makna kata secara } \\
\text { denotatif/konotatif }\end{array}$ \\
\cline { 2 - 3 } & $1,5,7,21,37,39$ & $\begin{array}{l}\text { 1.Memahami tokoh dan penokohan } \\
\text { dalam cerpen }\end{array}$ \\
\cline { 2 - 3 } & $3,13,17,31,33$ & $\begin{array}{l}\text { 2. Memahami latar dalam cerpen } \\
\text { (waktu, tempat, dan suasana) }\end{array}$ \\
\cline { 2 - 3 } & $9,19,23,35$ & $\begin{array}{l}\text { 3. Memahami alur cerpen } \\
\text { 4. Memahami tema dan amanat } \\
\text { cerpen }\end{array}$ \\
\hline
\end{tabular}

Ada dua cerita pendek yang dijadikan materi dalam kuesioner, yaitu cerita pendek berjudul "Kebaikan Berbuah Kebaikan" dan "Telepon Genggam”. Kedua cerita pendek tersebut diambil dari buku pelajaran bahasa Indonesia kelas VII. Pertanyaan yang diajukan dalam kuesioner terkait dengan cerita-cerita pendek tersebut dengan memperhatikan indikator-indikator yang sebelumnya telah ditetapkan melalui diskusi tim.

\section{HASIL DAN PEMBAHASAN}

Berdasarkan olah data, berikut ini dikemukakan hasil analisis deskriptif kuantitatifmengenai penguasaan kosakata (yang menjadi variabel $\mathrm{X}$ ) dan kemampuan memahami unsur intrinsik cerita pendek (yang menjadi variabel Y) siswa kelas VIII SMP di Kota Kendari.

\section{Penguasaan Kosakata}

Dalam mengukur hasil penguasaan kosakata, siswa diberi dua puluh pertanyaan yang berkaitan dengan pemahaman variabel kosakata. Berikut ini dikemukakan hasil dari pengolahan data.

a. PenguasaanAfiksasi/Kelas Kata

Berdasarkan hasil analisis data, diketahui bahwa umumnya jawaban responden berada pada kategori sedang dengan persentase $41 \%$. Artinya, dari 400 responden hanya 2 responden yang berada pada kategori sangat tinggi. Jadi, jawaban dari 2 responden 
dalam indikator ini benar semua. Umumnya, jawaban responden berada pada kategori sedang dan rendah. Ada 164 responden yang menjawab pertanyaan hanya 2 yang benar dari 4 pertanyaan yang berada pada kategori sedang. Sementara itu, ada 135 responden yang menjawab pertanyaan dengan hanya 1 benar, berada pada kategori rendah. Ada juga responden yang jawabannya salah semua berjumlah 34 responden dengan kategori sangat rendah.

Dari sebaran data dalam aspek memahami afiksasi/kelas kata, dapat disimpulkan bahwa kemampuan siswa dalam memahami afiksasi/kelas kata adalah sedang, bahkan cenderung rendah.

b. Penguasaan Kata Bersinonim-Berantonim

Hasil analisis memperlihatkan bahwa jawaban responden berada pada kategori tinggi, dan ada kecenderungan ke kategori sedang. Jumlah responden yang menjawab dengan jawaban 3 benar (tinggi) sebanyak 131 responden dan yang menjawab dengan 2 benar (sedang) sebanyak 119 responden. Sementara itu, untuk jawaban yang benar semua tidak ada. Responden yang menjawab salah semua berjumlah 73 orang.

Dari sebaran data dalam aspek penguasaan kata bersinonim/berantonim dapat disimpulkan bahwa kemampuan siswa dalam memahami kata bersinonim-berantonim adalah tinggi,tetapicenderung sedang.

\section{c. Penguasaan Kata Ameliorasi-Peyorasi, Perluasan-Penyempitan}

Berdasarkan hasil analisis, ditemukan bahwa dari 400 responden yang menjawab,ada 179 responden yang menjawab 1 soal benar. Yang menjawab benar semua hanya 5 responden, dan yang menjawab salah semua ada 76 responden. Dengan demikian, dapat dikatakan bahwa pemahaman siswa terhadap kata yang mengalami ameliorasi-peyorasi, perluasan-penyempitan berada pada kategori rendah.Olehkarenaitu, dapat disimpulkan bahwa tingkat penguasaan kata yang mengalami ameliorasi-peyorasi dan perluasan-penyempitan makna berada pada kategori rendah.

d. Penguasaan Kata Baku-Tidak Baku

Hasil analisis terkait penguasaan kata baku-tidak baku menunjukkan bahwa 218 responden yang menjawab 2 soal dengan benar. Bahkan, ada kecenderungan mengarah ke kategori rendah karena ada 99 responden yang menjawab hanya 1 yang benar. Ada 23 responden yang menjawab pertanyaan salah semua. Hanya 5 responden yang menjawab benar semua. Dengan demikian, pemahaman siswa terhadap kata baku-tidak 
baku umumnya berada pada kategori sedang. Penguasaan siswa dalam aspek memahami kata baku dan tidak baku ini dapat disimpulkan berada dalam kategori rendah.

e. Penguasaan Kata Bermakna Denotatif/Konotatif

Berdasarkan hasil analisis data terkait dengan penguasaan kata bermakna denotatif/konotatif diketahui bahwa pemahaman siswa terhadap makna kata secara denotatif dan konotatif berada pada kategori sedang, cenderung rendah. Dari 400 responden, ada 148 responden yang menjawab 2 pertanyaan dengan benar. Bahkan, ada kecenderungan ke kategori rendah sekali karena 93 responden yang menjawab soal salah semua.

\section{Kemampuan Memahami Unsur Intrinsik Cerita Pendek}

Dalam penelitian ini, kemampuan memahami unsur intrinsik cerita pendek memiliki empat indikator penilaian sebagai berikut: memahami tokoh dan penokohan; memahami latar; memahami alur; dan memahami tema dan amanat. Setiap indikator akan dideskripsikan untuk melihat kemampuan siswadalam memahami unsur intrinsik cerpen.

a. Kemampuan Siswa Memahami Tokoh dan Penokohan

Berdasarkan hasil analisis, dapat dikemukakan bahwa kemampuan responden dalam memahami tokoh dan penokohan berada pada kategori sedang. Dari 400 responden, ada 192 yang menjawab 3 benar dari 6 pertanyaan. Bahkan, nilai persentasenya hampir setengah dari keseluruhan nilai total, yaitu 48,00\%. Ada kecenderungan ke kategori rendah, yaitu dengan adanya 96 responden yang menjawab hanya 1 benar. Ada 23 responden yang jawabannya salah semua, dan hanya 25 responden yang menjawab dengan benar semua. Oleh karena itu, dapat disimpulkan bahwa kemampuan siswa dalam memahami aspek tokoh dan penokohan cerita pendek berada pada kategori sedang.

b. Kemampuan Siswa Memahami Latar Cerita

Kemampuan responden dalam memahami latar cerpen berada pada kategori tinggi. Indikator latar cerita yang ada dalam kuesioner memuat pemahaman atas latar tempat, latar waktu, dan latar suasana.

Dari 400 responden, ada 201 responden yang menjawab 2 dan 3 pertanyaan benar dari 5 pertanyaan. Ini artinya di atas 50 persen dari keseluruhan nilai. Yang masuk 
ke dalam kategori sangat rendah relatif sedikit, yaitu hanya 5 responden yang jawabannya salah semua.

c. Kemampuan Siswa Memahami Alur Cerita

Berdasarkan hasil analisis data terhadap kemampuan memahami alur cerita,dapat diketahui bahwa responden umumnya menjawab hanya 2 yang benar, sebanyak 179 responden. Jawaban responden ada kecenderungan ke kategori rendah, yaitu 159 responden yang menjawab hanya 1 benar. Sementara, responden yang menjawab benar semua hanya 4 orang.

d. Kemampuan Siswa Memahami Tema dan Amanat Cerita

Hasil analisis data terkait dengan kemampuan memahami tema dan amanat cerita menunjukkan kemampuan responden berada pada kategori sedang. Dari 400 responden, ada 127 yang menjawab pertanyaan hanya 2 benar. Ada kecenderungan kemampuan responden ke kategori tinggi karena ada 111 responden yang menjawab 2-3 pertanyaan dengan benar. Sementara yang menjawab pertanyaan salah semua ada 47 responden.

Berikut ini dikemukakan Tabel 3 yang memuat hasil ringkasan analisis deskriptif data mengenai Penguasaan Kosakata dan Kemampuan Memahami Unsur Intrinsik Cerpen.

Tabel 3

Ringkasan Analisis Deskriptif Data Penguasaan Kosakata dan Kemampuan Memahami Unsur Intrinsik Cerpen

\begin{tabular}{|c|c|c|c|c|}
\hline \multirow{2}{*}{ VARIABEL } & \multirow{2}{*}{$\begin{array}{l}\text { RATA- } \\
\text { RATA }\end{array}$} & \multicolumn{2}{|c|}{ JUMLAH } & \multirow{2}{*}{ KATEGORI } \\
\hline & & FREKUENSI & PERSENTASE & \\
\hline $\begin{array}{l}\text { PENGUASAAN } \\
\text { KOSAKATA }(\mathrm{X})\end{array}$ & 8,84 & 192 & 48,00 & Sedang \\
\hline Indikator 1 & 1,67 & 164 & 41.00 & Sedang \\
\hline Indikator 2 & 2,75 & 131 & 32.75 & Tinggi \\
\hline Indikator 3 & 1,28 & 179 & 44,75 & Rendah \\
\hline Indikator 4 & 1,80 & 218 & 54,50 & Sedang \\
\hline Indikator 5 & 1,34 & 149 & 37,00 & Sedang \\
\hline $\begin{array}{c}\text { KEMAMPUAN } \\
\text { MEMAHAMI UNSUR } \\
\text { INTRINSIK CERPEN } \\
(\mathrm{Y}) \\
\end{array}$ & 10,42 & 181 & 45,25 & Sedang \\
\hline Indikator 1 & 3,23 & 177 & 44,25 & Tinggi \\
\hline Indikator 2 & 2,59 & 201 & 50,25 & Tinggi \\
\hline Indikator 3 & 1,67 & 179 & 44,75 & Sedang \\
\hline Indikator 4 & 2,93 & 127 & 31,75 & Sedang \\
\hline
\end{tabular}


Analisis deskriptif data dalam Tabel 3 dapat diuraikan dengan penjelasan sebagai berikut. Penguasaan kosakata siswa SMP kelasVII di Kota Kendari, memiliki nilai rata-rata sebesar 8,84 (48\%) berada pada kategori sedang. Indikator penguasaan kosakata yang paling menonjol memberikan kontribusi adalah indikator memahami kata bersinonim/berantonim dengan nilai rata-rata $2,75(32,7 \%)$. Sementara, indikator memahami kata yang mengalami ameliorasi-peyorasi, perluasan-penyempitan adalah yang terendah dengan nilai rata-rata 1,28 $(44,75 \%)$.

Kemampuan memahami unsur intrinsik cerpen siswa SMP kelasVII di Kota Kendari, memiliki nilai rata-rata sebesar 10,42 (45,25), pada umumnya termasuk kategori sedang. Indikator kemampuan memahami unsur intrinsik cerpen yang paling menonjol memberikan kontribusi adalah indikator memahami tokoh dan penokohan dalam cerpen dengan nilai rata-rata $3,23(44,25 \%)$.

\section{Hubungan antara Penguasaan Kosakata dan Kemampuan Memahami Unsur Intrinsik Cerpen}

Untuk melihat hubungan kedua variable antara penguasaan kosakata dan kemampuan memhami unsur intrinsik cerpen digunakan uji Korelasi Product Moment. Tabel 4 berikut menunjukkan hasil uji korelasi berdasarkan indikator variabel $\mathrm{X}$ dan variabel Y.

Tabel 4

Uji Korelasi Berdasarkan Indikator Variabel X dan Y

\begin{tabular}{|c|c|c|c|c|}
\hline UJI KORELASI & $\mathrm{r}_{\text {hitung }}$ & $r_{\text {tabel }}$ & Sig. $(\rho)$ & Keputusan \\
\hline \multicolumn{5}{|l|}{ VARIABEL X } \\
\hline $\mathrm{X}_{1}-\mathrm{X}$ & 0,522 & \multirow{5}{*}{0,250} & \multirow{5}{*}{0,000} & Ho Ditolak \\
\hline$X_{2}-X$ & 0,589 & & & Ho Ditolak \\
\hline $\mathrm{X}_{3}-\mathrm{X}$ & 0,461 & & & Ho Ditolak \\
\hline $\mathrm{X}_{4}-\mathrm{X}$ & 0,409 & & & Ho Ditolak \\
\hline $\mathrm{X}_{5}-\mathrm{X}$ & 0,459 & & & Ho Ditolak \\
\hline \multicolumn{5}{|l|}{ VARIABEL Y } \\
\hline $\mathrm{Y}_{1}-\mathrm{Y}$ & 0,746 & \multirow{4}{*}{0,250} & \multirow{4}{*}{0,000} & Ho Ditolak \\
\hline $\mathrm{Y}_{2}-\mathrm{Y}$ & 0,639 & & & Ho Ditolak \\
\hline $\mathrm{Y}_{3}-\mathrm{Y}$ & 0,359 & & & Ho Ditolak \\
\hline $\mathrm{Y}_{4}-\mathrm{Y}$ & 0,729 & & & Ho Ditolak \\
\hline Xdengan Y & 0,359 & 0,250 & 0,000 & Ho Ditolak \\
\hline
\end{tabular}

Tabel 4memperlihatkan bahwa $r_{\text {hitung }}=0,359>r_{\text {tabel }}=0,250$ dan nilai Sig $(\rho)<\alpha$ $=0,05$. Artinya, penguasaan kosakata memiliki hubungan yang positif dengan 
kemampuan memahami unsur intrinsik cerpen pada siswa SMP kelas VIII di Kota Kendari.

Setelah diketahui ada hubungan yang positif antara pengusaan kosakata dan kemampuan memahami unsur intrinsik cerpen pada siswa SMP kelas VIII di Kota Kendari, berikutnya adalah dilakukan uji Regresi Linear. Uji regresi digunakan untuk menentukan sebab-akibat antara variable Penguasaan Kosakata dan variable Memahami Unsur Intrinsik Cerpen).

Tabel 5 berikut memuat hasil uji regresi linear berdasarkan indikator variabel X dan variabel Y.

Tabel 5

Uji Regresi Linear Berdasarkan Indikator Variabel X dan Y

\begin{tabular}{|c|c|c|c|c|}
\hline UJI REGRESI LINEAR & $F_{\text {hitung }}$ & $\mathrm{F}_{\text {tabel }}$ & Sig. $(\rho)$ & Keputusan \\
\hline VARIABEL X & & \multirow{6}{*}{3,888} & \multirow{6}{*}{0,000} & \\
\hline$X_{1}-X$ & 149,106 & & & Ho Ditolak \\
\hline$X_{2}-X$ & 211,834 & & & Ho Ditolak \\
\hline$X_{3}-X$ & 107,144 & & & Ho Ditolak \\
\hline $\mathrm{X}_{4}-\mathrm{X}$ & 80,167 & & & Ho Ditolak \\
\hline $\mathrm{X}_{5}-\mathrm{X}$ & 106,328 & & & Ho Ditolak \\
\hline \multicolumn{5}{|l|}{ VARIABEL Y } \\
\hline $\mathrm{Y}_{1}-\mathrm{Y}$ & 500.362 & \multirow{4}{*}{3,888} & \multirow{4}{*}{0,000} & Ho Ditolak \\
\hline $\mathrm{Y}_{2}-\mathrm{Y}$ & 275,320 & & & Ho Ditolak \\
\hline $\mathrm{Y}_{3}-\mathrm{Y}$ & 58,696 & & & Ho Ditolak \\
\hline $\mathrm{Y}_{4}-\mathrm{Y}$ & 450,697 & & & Ho Ditolak \\
\hline $\mathrm{X}$ terhadap $\mathrm{Y}$ & 58,893 & 3,888 & 0,000 & Ho Ditolak \\
\hline
\end{tabular}

Tabel 5 menunjukkan, bahwaF $F_{\text {hitung }}=58,893>\mathrm{F}_{\text {tabel }}=3,888$ dan nilai Sig $(\rho)<\alpha=$ 0,05. Hasil uji regresi linear berdasarkan variabel $\mathrm{X}$ dan variabel $\mathrm{Y}$ ini menunjukkan penguasaan kosakata berpengaruh positif terhadap kemampuan memahami unsur intrinsik cerita pendek pada siswa SMP kelas VIII di Kota Kendari.

Setelah diketahui ada hubungan positif antara penguasaan kosakata dan kemampuan memahami unsur intrinsik cerita pendek pada siswa SMP, selanjutnya yang penting dilakukan adalah uji signifikansi dari hipotesis. Tujuannya adalah untuk memperkuat penerimaan dan pemberlakuan hipotesis dari penelitian sehingga dapat digeneralisasikan pada populasi.

Dalam Tabel 6 berikut ini diperlihatkan hasil uji signifikansi berdasarkan indikator variabel $\mathrm{X}$ dan variabel $\mathrm{Y}$. 
Tabel 6

Uji Signifikansi Berdasarkan Indikator Variabel X dan Y

\begin{tabular}{|c|c|c|c|c|}
\hline UJI SIGNIFIKANSI & $t_{\text {hitung }}$ & $\mathrm{t}_{\text {tabel }}$ & Sig. $(\rho)$ & Keputusan \\
\hline VARIABEL X & & \multirow{6}{*}{1,645} & \multirow{6}{*}{0,000} & \\
\hline $\mathrm{X}_{1}-\mathrm{X}$ & 30,028 & & & Ho Ditolak \\
\hline$X_{2}-X$ & 22,249 & & & Ho Ditolak \\
\hline$X_{3}-X$ & 40,489 & & & Ho Ditolak \\
\hline$X_{4}-X$ & 25,133 & & & Ho Ditolak \\
\hline $\mathrm{X}_{5}-\mathrm{X}$ & 43,389 & & & Ho Ditolak \\
\hline \multicolumn{5}{|l|}{ VARIABEL Y } \\
\hline $\mathrm{Y}_{1}-\mathrm{Y}$ & 23,025 & \multirow{4}{*}{1,645} & \multirow{4}{*}{0,000} & Ho Ditolak \\
\hline $\mathrm{Y}_{2}-\mathrm{Y}$ & 17,000 & & & Ho Ditolak \\
\hline $\mathrm{Y}_{3}-\mathrm{Y}$ & 28,029 & & & Ho Ditolak \\
\hline $\mathrm{Y}_{4}-\mathrm{Y}$ & 22,571 & & & Ho Ditolak \\
\hline X terhadap Y & 14,246 & 1,645 & 0,000 & Ho Ditolak \\
\hline
\end{tabular}

Tabel 6 menunjukkan hasil bahwa $t_{\text {hitung }}=14,246>t_{\text {tabel }}=1,645$ dan nilai Sig $(\rho)<\alpha=0,05$. Dari hasil uji signifikansi berdasarkan indikator variabel $\mathrm{X}$ dan $\mathrm{Y}$ diketahui bahwa penguasaan kosakata memiliki hubungan yang signifikan dengan Kemampuan Memahami Unsur Intrinsik Cerpen pada Siswa SMP kelas VIII di Kota Kendari.

Untuk melengkapi penghitungan statistik dalam penelitian, juga dilakukan uji Koefisien Determinasi. Tujuannya adalah untuk memprediksi seberapa besar kontribusi Penguasaan Kosakata terhadap Kemampuan Memahami Unsur Intrinsik Cerpen pada Siswa SMP. Tabel 7 berikut ini memuat hasil uji koefisiensi determinasi berdasarkan indikator variabel $\mathrm{X}$ dan variabel $\mathrm{Y}$.

Tabel 7

Uji Koefisien Determinasi Berdasarkan Indikator Variabel X dan Y

\begin{tabular}{|c|c|c|c|}
\hline VARIABEL & $\mathrm{R}$ & $r^{2} \times 100 \%$ & Keterangan \\
\hline \multicolumn{3}{|l|}{ VARIABEL X } & \multirow{9}{*}{$\begin{array}{c}\mathrm{r}^{2} \mathrm{x} 100 \% \text { artinya } \\
\text { besarnya kontribusi } \\
\text { variabel bebas } \\
\text { terhadap variabel } \\
\text { terikat }\end{array}$} \\
\hline$X_{1}-X$ & 0,522 & $27,3 \%$ & \\
\hline $\mathrm{X}_{2}-\mathrm{X}$ & 0,589 & $34,7 \%$ & \\
\hline $\mathrm{X}_{3}-\mathrm{X}$ & 0,461 & $21,2 \%$ & \\
\hline$X_{4}-X$ & 0,409 & $16, * \%$ & \\
\hline$X_{5}-X$ & 0,459 & $21,1 \%$ & \\
\hline \multicolumn{3}{|l|}{ VARIABEL Y } & \\
\hline $\mathrm{Y}_{1}-\mathrm{Y}$ & 0,746 & $55,7 \%$ & \\
\hline $\mathrm{Y}_{2}-\mathrm{Y}$ & 0,639 & $40,9 \%$ & \\
\hline
\end{tabular}




\begin{tabular}{ccc}
\hline $\mathrm{Y}_{3}-\mathrm{Y}$ & 0,359 & $12,9 \%$ \\
\hline $\mathrm{Y}_{4}-\mathrm{Y}$ & 0,729 & $53,1 \%$ \\
\hline Xterhadap Y & 0,359 & $12,9 \%$ \\
\hline
\end{tabular}

Berdasarkan Tabel 7, apabila uraian berdasarkan indikator variabel X, yang paling tinggi memberikan kontribusi terhadap penguasaan kosakata adalah indikator kedua, yaitu "memahami kata yang mengalami ameliorasi-peyorasi, perluasanpenyempitan" sebesar 34,7\%. Sedangkan untuk variabel Y, indikator yang paling tinggi memberikan kontribusi terhadap kemampuan memahami unsur intrinsik cerpen adalah indikator pertama, yaitu "memahami tokoh dan penokohan dalam cerpen" sebesar $55,7 \%$.

Dengan demikian secara umum, besarnya koefisien determinasi atau kontribusi penguasaan kosakata $(\mathrm{X})$ terhadap kemampuan memahami unsur intrinsik cerpen $(\mathrm{Y})$ siswa SMP kelas VIII di Kota Kendari adalah 12,9\%, dan selebihnya dipengaruhi oleh faktor lain yang tidak terkait dengan penelitian ini.

\section{PENUTUP}

Berikut dikemukakan beberapa simpulan hasil penelitian sesuai dengan permasalahan penelitian.

Penguasaan kosakata siswa SMP kelas VIII di Kota Kendari, memiliki nilai ratarata sebesar 8,84 (48\%) yang masuk dalam kategori sedang. Indikator penguasaan kosakata yang paling menonjol memberikan kontribusi adalah indikator memahami kata yang mengalami ameliorasi-peyorasi, perluasan-penyempitan dengan nilai rata-rata 2,75 $(32,7 \%)$.

Kemampuan memahami unsur intrinsik cerpen siswa SMP kelas VIII di Kota Kendari, memiliki nilai rata-rata sebesar 10,42 $(45,25)$ pada umumnya termasuk kategori sedang. Indikator kemampuan memahami unsur intrinsik cerpen yang paling menonjol memberikan kontribusi adalah indikator memahami tokoh dan penokohan dalam cerpen dengan nilai rata-rata $3,23(44,25 \%)$.

Penguasaan kosakata memiliki hubungan yang positif dan signifikan dengan kemampuan memahami unsur intrinsik cerpen pada siswa SMP kelas VIII di Kota Kendari, di mana $\mathbf{r}_{\text {hitung }}=0,359>\mathrm{r}_{\text {tabel }}=0,250$ dan nilai Sig $(\rho)<\alpha=0,05$, dan $t_{\text {hitung }}=$ $14,246>\mathrm{t}_{\text {tabel }}=1,645$ dan nilai Sig $(\rho)<\alpha=0,05$, maka Ho ditolak, artinya pengusaan 
kosakata memiliki hubungan yang positif dan signifikan dengan kemampuan memahami unsur intrinsik cerpen pada siswa SMP kelas VIII di Kota Kendari. Besarnya kontribusi penguasaan kosakata $(\mathrm{X})$ terhadap kemampuan memahami unsur intrinsik cerpen (Y) siswa SMP kelas VIII di Kota Kendari adalah 12,9\%, dan selebihnya dipengaruhi oleh faktor lain yang tidak terkait dengan penelitian ini.

\section{DAFTAR PUSTAKA}

Andayani. (2009). Bahasa Indonesia. Surakarta: Panitia Sertifikasi Guru (PSG) Rayon 13 Surakarta..

Chaer, A. (2011). Ragam Bahasa Indonesia. Jakarta: RinekaCipta.

Dirgantara. (2012). Problematika Pembelajaran Bahasa dan Sastra di Sekolah. In Bunga Rampai.Pelangi Bahasa dan Budaya Indonesia. Yogyakarta: Jalu Sentanu.

Djiwandono. (2008). Tes Bahasa dalam Pengajaran. Bandung: ITB.

Djiwandono. (2011). Tes Bahasa:Pegangan bagi Pengajar Bahasa. Jakarta: Indeks.

Hamid, M. A. (2007). Pengajaran Sastra di Sekolah: Antara Harapan dan Kenyataan. Retrieved from https://gemasastrin.wordpress.com.

Kasno. (2014). Kamus sebagai Sumber Rujukan dan Pengajaran Kosakata. Jakarta: Pusat Bahasa.

Noor, R. (2005). Pengantar Pengkajian Sastra. Semarang: Fasindo.

Nurgiyantoro, B. (2009). Teori Pengkajian Fiksi. Yogyakarta: Gadjah Mada University Press.

Rosdiana, Yusi, D. (2008). Bahasa dan Sastra Indonesia di SD. Jakarta: Universitas Terbuka.

Tarigan, D. (1991). Materi Pokok Pendidikan Bahasa Indonesia 1. Jakarta.

Tarigan, D. (2015). Pengajaran Kosakata. Bandung: Angkasa.

Uniawati, Zakiyah M. Husba, dan R. (2014). Penelitian Sikap Bahasa Siswa Sekolah Menengah Pertama Kota Kendari. Kendari. Kendari.

Wicaksono, A. (2011). Hubungan Minat terhadap Karya Sastra dan Kemampuan Membaca Pemahaman dengan Kemampuan Apresiasi Sastra Siswa Kelas Dua SMU 1 Sleman. Retrieved from http://andriew.blogspot.com/2011/04/hubungan-minat-terhadap-karya-sastra.html.

Widaningsih. (2014). Strategi Curiosity Based Learning dalam Pembelajaran Menulis Teks Ilmiah Populer di Kelas VII SMP Negeri 3 Bandung. Jurnal Ranah, Vol. 3(Juli 2014), 45-59. DOI: https://doi.org/10.26499/rnh.v3i1.46

Zalmansyah, A. (2018). Teknik Cooperative Integrated Reading and Composition (CIRC) untuk Meningkatkan Kemampuan Menulis. Jurnal Ranah, Vol. 7, No.2 (Desember 2018), 229—246. DOI: https://doi.org/10.26499/rnh.v7i2.573

Zuriah, N. (2005). Metodologi Penelitian Sosial dan Pendidikan: Teori-Aplikasi. Jakarta: Bumi Aksara. 